DOI 10.17516/2782-2214-0010

УДК 691.175

\title{
SECONDARY USE OF PACKAGING MATERIALS IN CONTACT WITH FOOD Tatyana I. Chalykh*
}

Plekhanov Russian University of Economics, Moscow, Russian Federation

\begin{abstract}
The problems of safe use of packaging for contact with food are discussed. In particular, the possibility of migration of low molecular weight chemicals from packaging materials to a consumer product, which above a certain established threshold value, represents a significant risk, has been investigated. Particular attention is paid to packaging that contains recycled materials. The problems that need to be solved for the safe use of recycled materials in packaging are discussed.

An example of the use of polyethylene terephthalate (PET), which has passed the stages of controlled aging in mechanical recycling, is considered. The change in the microstructure of the polymer from cycle to cycle, its chemical composition and physical parameters were assessed by methods: physico-mechanical, optical and electron microscopy with X-ray microanalysis, FT-IR spectroscopy, viscosity (melt flow rate), biotesting. A noticeable effect of the aging process on both the original primary polymer and the recycled one is shown. Moreover, the biotesting method revealed sufficient toxicity of both secondary PET, which has a certificate, and PET flakes.

As the oxo-degradable packaging, two samples of industrial polymer packaging were chosen, which contained different oxo-degradable additives: $\mathrm{d} 2 \mathrm{w}$ and "REVERTE". The ciliates Tetrahymena pyriformis were used as test objects. Research has shown that a declared supplement can only be a declaration. The analysis of the microstructure and chemical composition of the films by X-ray diffraction microanalysis revealed the absence of transition metal ions. The test objects of the ciliates behaved practically the same in control solutions and in the presence of the studied films with the $\mathrm{d} 2 \mathrm{w}$ oxo additive, which reliably indicates the absence of these additives in the films.

The prospects of using the methods of biotesting of packaging materials have been proved as they allow, without the use of model environments and sanitary-chemical studies, to give a relatively quick conclusion about the safety of the material and its suitability for contact with food.
\end{abstract}

Keywords: packaging safety, food products, secondary polymers, polyethylene terephthalate, biotesting.

Citation: Chalykh, T. I. (2021). Secondary use of packaging materials in contact with food. Trade, service, food industry. Vol. 1(1). Pp. 104-116.

\section{ВТОРИЧНОЕ ИСПОЛЬЗОВАНИЕ МАТЕРИАЛОВ В УПАКОВКАХ, КОНТАКТИРУЮЩИХ С ПИЩЕВЫМИ ПРОДУКТАМИ Татьяна Ивановна Чалых}

ФГБОУ ВО «Российский экономический университет им. Г. В. Плеханова», Москва, Российская Федерация

Аннотация. Обсуждаются проблемы безопасного использования упаковки для контакта с пищевыми продуктами. В частности, исследована возможность миграции низкомолекулярных химических веществ из упаковочных материалов в потребительский товар, что выше некоторого установленного порогового значения представляет собой значительный риск. Особое внимание уделено упаковке, которая содержит в своем составе вторичные материалы. Обсуждаются проблемы, которые необходимо решить для безопасного использования вторичных материалов в упаковке.

Рассмотрен пример использования полиэтилентерефталата (ПТЭФ), который прошел стадии контролированного старения в механическом рециклинге. Изменение

(C) Siberian Federal University. All rights reserved

*Corresponding author E-mail address: TChalykh.TI@ rea.ru 
микроструктуры полимера от цикла к циклу, его химического состава и физических параметров оценивалось методами: физико-механическими, оптической и электронной микроскопии с рентгеновским микроанализом, ИК-Фурье спектроскопии, вязкости (показатель текучести расплава), биотестирования. Показано заметное влияние процесса старения и на исходный первичный полимер, и на возвращенный в производство. Более того, методом биотестирования выявлена достаточная токсичность как вторичного ПЭТФ, который имеет сертификат, так и ПЭТФ флексов.

В качестве оксо-разлагаемой упаковки было выбрано два образца промышленной полимерной упаковки, которые содержали разные оксо-разлагаемые добавки: $\mathrm{d} 2 \mathrm{w}$ и «REVERTE». В качестве тест-объектов использовали инфузорий Tetrahymena pyriformis. Исследования показали, что заявленная добавка может быть только декларацией. Проведенный анализ микроструктуры и химического состава пленок методом рентгеноструктурного микроанализа выявил отсутствие ионов переходных металлов. Тестобъекты инфузории вели себя практически одинаково в контрольных растворах и в присутствии исследуемых пленок с оксо-добавкой $\mathrm{d} 2 \mathrm{w}$, что достоверно свидетельствует об отсутствии указанных добавок в пленках.

Доказана перспективность использования методов биотестирования упаковочных материалов как позволяющих без применения модельных сред и санитарно-химических исследований давать сравнительно быстрое заключение о безопасности материала и его пригодности для контакта с пищевыми продуктами.

Ключевые слова: безопасность упаковки, пищевые продукты, вторичные полимеры, полиэтилентерефталат, биотестирование.

Введение. Распоряжением Правительства Российской Федерации от 30.08.2019 г. №1931-p утверждена «Стратегия развития машиностроения для пищевой и перерабатывающей промышленности Российской Федерации на период до 2030 года» [1]. В область развития в этой стратегии входят все виды пищевого и перерабатывающего оборудования, в том числе и оборудование для расфасовки, упаковки и розлива. Это позволяет надеяться, что продовольственная безопасность будет обеспечена не только со стороны производства отечественной пищевой продукции, но и со стороны применения отечественной упаковки и упаковочного оборудования.

К настоящему времени в товароведении, маркетинге и торговле сложилось понимание, что упаковка - это сформировавшаяся однородная группа непродовольственных товаров, объединенная функциональным показателем - назначения. Упаковка (тара) четко различается по типам, видам, разновидностям и наименованиям. Поэтому упаковка как товар обладает комплексом потребительских свойств и характеристиками, присущими товару (ассортиментными, качественными, количественными и др.), свободно обращается на рынке [2].

По данным ФАО/ВОЗ ежегодно в мире теряется или попадает в отходы большое количество пищевой продукции. Так, если в развитых странах теряется около 50\% пищевых продуктов, то эти потери связаны со строгим контролем соблюдения правил торговли. Перенасыщенный рынок продукции вынужден снимать с продажи упакованные товары с истекающим или истекшим сроком годности. В развивающихся странах также есть потери продукции - 30-35\%, но за счет недостаточного взаимодействия по цепи поставок продукции и некачественной упаковки или ее отсутствия [3].

Существуют два разных подхода в технологиях упаковывания, что определяет разные технологические линии:

FS - технология наполнения и упаковывания (fill - seal).

FFS - технология формования, наполнения и упаковывания (form- fill - seal).

Seal - означает и заваривание, и запечатывание, и герметизацию, как финальный этап формирования первичной упаковки (тары), интимно соприкасающейся с упакованным продуктом. 
Различие этих подходов предполагает, что в первом случае упаковка уже сформована, тогда как во втором случае возможно формирование упаковки (тары) одновременно с процессом упаковывания и запечатывания, что снижает потери.

Рынок упаковки не является самодостаточным - все его участники тесно связаны с производителями тары, производителями упаковочного оборудования, обслуживанием процесса упаковывания. Упаковка является объектом для разных отраслей промышленности и областей научных знаний, поскольку существует интегрированная система, включающая области производства продукции - переработки продукции - упаковывания, что тесно связано с производством упаковочных материалов и производством упаковки. Ее производство не может значительно превышать производство продукции.

В торговле существуют специальные методические подходы и правила обращения с упаковкой и отходами упаковки, которые позволяют правильно выбирать материал упаковки для сохранения продукции в процессе ее обращения. Различают промышленную упаковку и торговую упаковку. В случае торговой упаковки ее могут осуществлять как продавец (взвешивание, упаковывание и маркирование), так и непосредственно сам потребитель в процессе самообслуживания. На этой стадии существует потенциальный соблазн заработать на упаковке: когда недобросовестный продавец не обнуляет на весах массу упаковки при взвешивании. Мы провели исследование, которое показало следующее. На торговых предприятиях предлагают для самообслуживания полимерный пакеты разной массы - от 0,7 до 6,8 г. Если масса упаковки на весах не обнулена, то с каждым продуктом потребитель покупает упаковку по цене пищевого продукта. Была определена среднерыночная цена за 100 г орехов разных видов, и расчетным путем показано, что стоимость самого большого пакета массой 6,8 г с разными видами орехов составляет от 7,7 руб. до 26,4 руб., самого маленького массой 0,7 г составила от 0,9 до 2,8 руб./пакет. Цена среднего полимерного пакета для бутербродов 0,4-0,5 руб.

Хорошо известно, что для целей упаковки применяют разные типы материалов сталь, алюминий, стекло, картон и бумага, полимерные материалы. Полимеры среди перечисленных упаковочных материалов являются самыми «молодыми», поскольку их широкое применение началось во второй половине XX века, тогда как другие материалы используют десятилетиями (алюминий) и веками. Для целей идентификации упаковочных материалов в РФ и ЕАЭС, используют ТР ТС 005/2011 «О безопасности упаковки», который регламентирует также и требования к безопасности упаковки и упаковочных материалов.

В табл. 1 приведены обобщенные данные по структуре используемых материалов в разных регионах.

Таблица 1. Основные типы упаковки и их доля в структуре использования

Table 1. The main types of packaging and their share in the structure of use

\begin{tabular}{|c|c|c|}
\hline $\begin{array}{c}\text { Тип упаковки и доля в } \\
\text { структуре, \% } \\
\text { (усреднено по странам) }\end{array}$ & $\begin{array}{c}\text { Структура российского } \\
\text { рынка упаковки для } \\
\text { пищевой продукции, \% } \\
\text { (по данным [4]) }\end{array}$ & $\begin{array}{c}\text { Международное буквенно- } \\
\text { цифровое обозначение } \\
\text { материала упаковки }\end{array}$ \\
\hline $\begin{array}{l}\text { Картонно-бумажная } \\
35-37\end{array}$ & 36 & PAP $20,21,22$ \\
\hline Стеклянная 15-17 & 12 & Gl 70, 71, 72 \\
\hline Металлическая 7-10 & 10 & FE 40. AL 41 \\
\hline жесткие пластики 23-25 & 18 & $\begin{array}{c}\text { PE 1, HDPE 2, PVC 3, LDPE 4, } \\
\text { PP 5, PS 6, Other } 7\end{array}$ \\
\hline $\begin{array}{l}\text { гибкие пластики (пленки) } \\
15-17\end{array}$ & 20 & $\begin{array}{c}\text { PE 1, HDPE 2, PVC 3, LDPE 4, } \\
\text { PP 5, PS 6, Other } 7\end{array}$ \\
\hline Деревянная & \multirow[b]{2}{*}{4 (прочие) } & FOR 40,41 \\
\hline $\begin{array}{l}\text { и текстильная, } \\
\text { суммарно 3-5 }\end{array}$ & & TEX 60, 61 \\
\hline
\end{tabular}


Регламентирование безопасности базируется на оценке рисков, которые должны быть минимальными, и поэтому используется концепция предельно-допустимого количества вещества - ПДК или допустимого уровня - ДУ. Это минимально возможное количество потенциального опасного или вредного химического соединения, которое при попадании в организм человека не окажет значительных изменений здоровья ни у него самого, ни у его потомства. Оценивание риска проводится на основании сравнения значений этих величин, приведенных в нормативных документах, и реально обнаруженных в лабораторных исследованиях.

В США федеральное агентство FDA действует на основании Федерального закон о продуктах питания, лекарствах и косметике (FFDCA). Основное положение для материалов, контактирующих с пищевыми продуктами //food contact substance (FCS), имеет требование предварительного разрешения, что любое вещество, которое может стать компонентом пищи, должно быть: признанным безопасным (GRAS), либо получить оценку по TOR (на основании ранее установленных пороговых значений). При анализе безопасности упаковки в США применяют следующие модельные среды: для жидких и кислых продуктов - $10 \%$ этанол; для слабоалкогольных и крепких алкогольных напитков - 10 или 50\% этанол; для жиросодержащих продуктов - масла растительного происхождения, масло НВ307, Миглиол 812 (глицерил каприлокапрат C8/C10) и другие.

В ЕС Регламент ЕС № 1935/2004 является основным законодательством, которое применяется ко всем материалам, контактирующим с пищевыми продуктами. Он устанавливает, что такие материалы должны быть безопасны и не изменять свойства пищи недопустимым образом. Статья 3 закона устанавливает, что материалы и изделия должны быть изготовлены в соответствии с надлежащей производственной практикой (НПП//GMP) [5].

В ЕС для анализа общей миграции из полимерного слоя в пищевой продукт чаще всего используются четыре имитатора, так как они имеют более простую химическую форму, чем продукты питания. Имитаторами, рекомендованными для тестирования миграции, являются: вода (имитатор А) представляет жидкие продукты (pН> 4,5); 3\%-ный водный раствор уксусной кислоты (имитатор В), представляет кислые жидкие продукты (рН $<4,5) ; 10 \%$ водный раствор этанола (имитатор С) для имитации алкогольных пищевых продуктов, и оливковое масло (имитатор D) для жирной пищи [6].

В Российской Федерации для оценки миграции используется 8 стандартных модельных сред, которые зависят от группы продуктов в соответствии с ТР ТС 005/2011 «О безопасности упаковки» [7]. Это позволяет оценивать безопасность всех упаковочных материалов, а не только полимерных упаковок.

Целью настоящего исследования явилась оценка целесообразности вторичного использования полимерных материалов в упаковках, контактирующих с пищевыми продуктами.

Материалы и методы. С целью моделирования процессов, происходящих с полимерной упаковкой после ее использования, применен подход контролируемого старения полимерного материала. Для доказательства процесса старения полимера под действием пищевых сред исследовали покрытие жестяной банки после хранения.

Объектом исследования служил полиэтилентерефталат (ПЭТФ) первичный марки Ekopet, который подвергали неоднократной переработке в экструдере при температурах 245$270^{\circ} \mathrm{C}$ от цикла к циклу, что позволило «накапливать» в полимере изменения структуры в результате термомеханического старения.

Изменение микроструктуры полимера от цикла к циклу, его химического состава и физических параметров оценивалось такими стандартными методами, как физикомеханические, оптической и электронной микроскопии с рентгеновским микроанализом, ИК-Фурье спектроскопии, вязкости (показатель текучести расплава), биотестирования.

Состояние полимерного покрытия металлической (жестяной) упаковки идентифицировали после длительного хранения пищевых продуктов в реальных условиях. 
Исследование топографии, морфологии поверхности упаковки и элементного анализа осуществлялось методом растровой электронной микроскопии и рентгеновского микроанализа с помощью сканирующего электронного микроскопа фирмы JEOL Ltd (Япония), снабженного энергетическим детектором WINEDEX (ФРГ).

Обсуждение. На рис. 1 приведены микрофотографии внешней и внутренней поверхности жестяной банки после длительного контакта с пищевой средой (ананасы) в пределах срока годности пищевого продукта, рекомендованного производителем. Как видно, внешняя поверхность практически однородна, тогда как внутренняя поверхность претерпела изменения под действием пищевой среды: появился налет рыжего (б), черного (в) и серого (г) оттенка цвета. При большем увеличении (рис.1б) отчетливо видно травление поверхности [8].

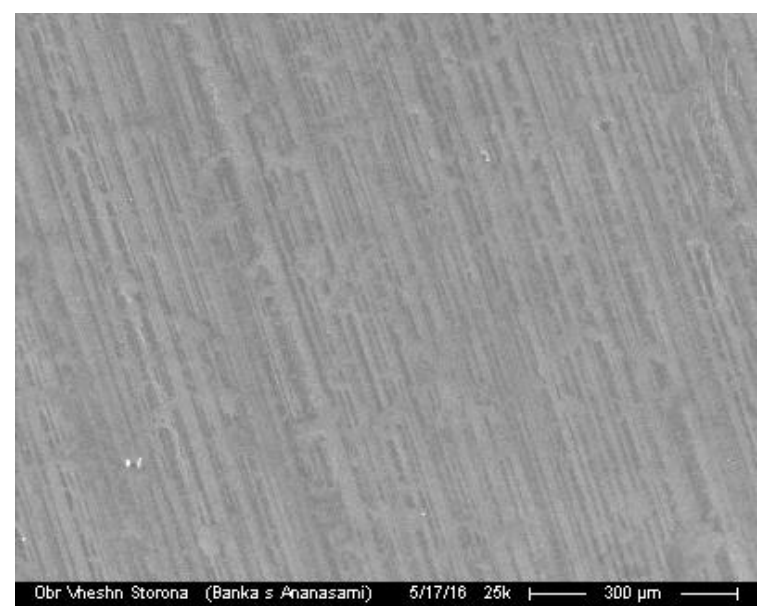

a

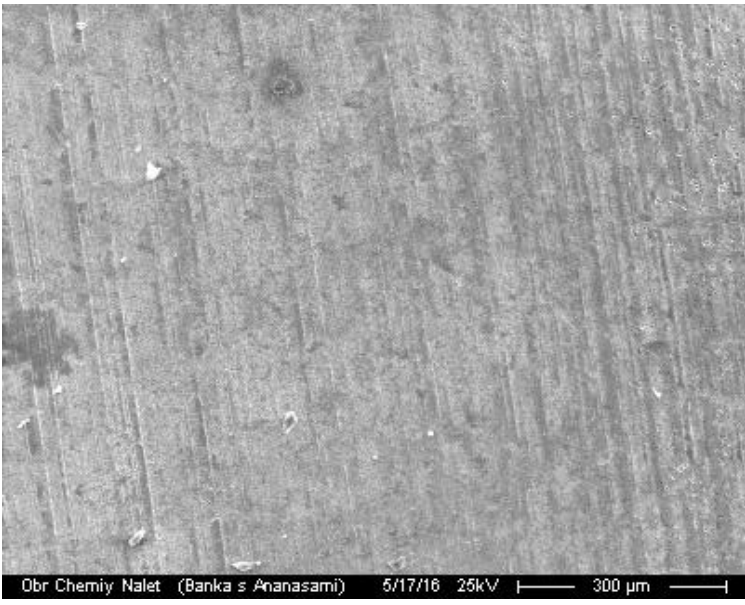

B

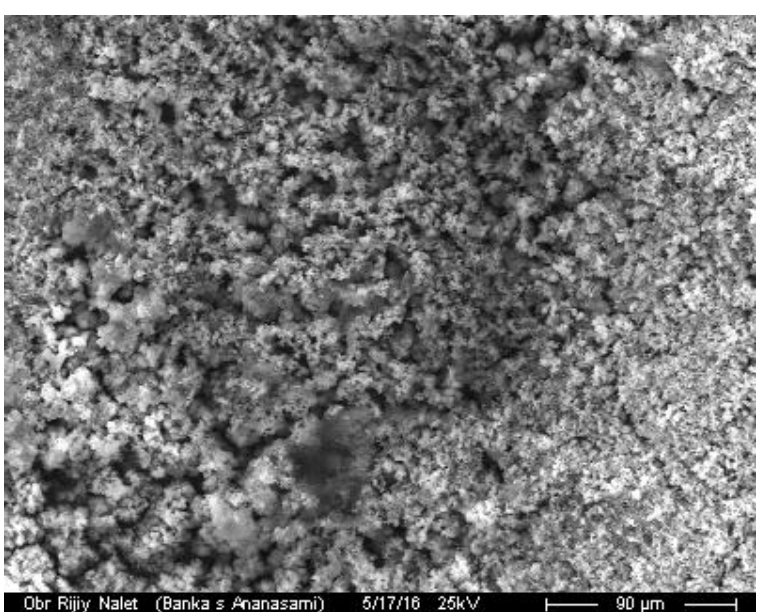

6

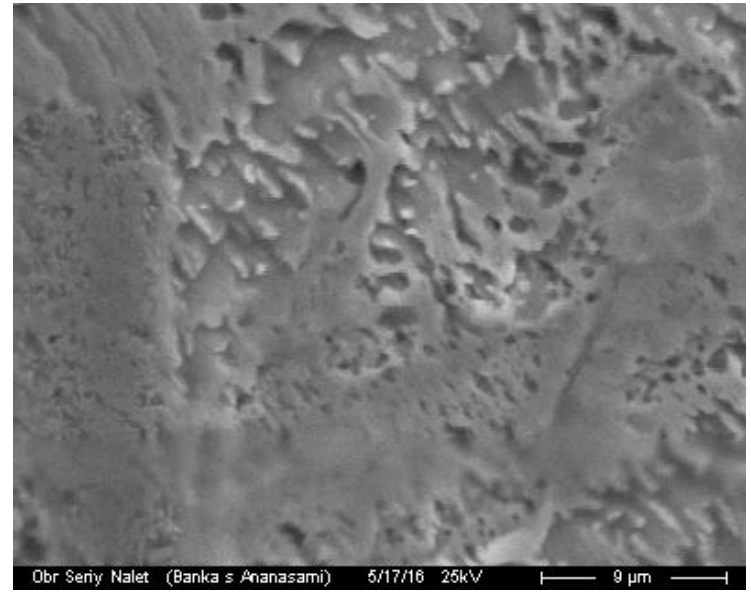

$\Gamma$

Рисунок 1. Микрофотографии поверхности жестяной банки после хранения пищевого продукта: а - внешняя; б - г - внутренняя поверхность (SEM фирмы Jeol)

Figure 1. Micrographs of the surface of a tin can after storing a food product: a outer surface; $b$ - d - inner surface (SEM by Jeol)

Сравнение результатов микроанализа поверхности показано на рис. 2 а, б. Спектры характеристического рентгеновского излучения от поверхности показывают, что на внутренней стороне банки заметно уменьшаются пики олова, $\mathrm{Sn}$ и увеличивается интенсивность пиков железа $\mathrm{Fe}$. Полученные результаты однозначно показывают разрушение поверхности жести, по всей вероятности из-за очень тонкого слоя олова или недостаточно качественного полимерного покрытия для олова, или его растрескивания или старения. 


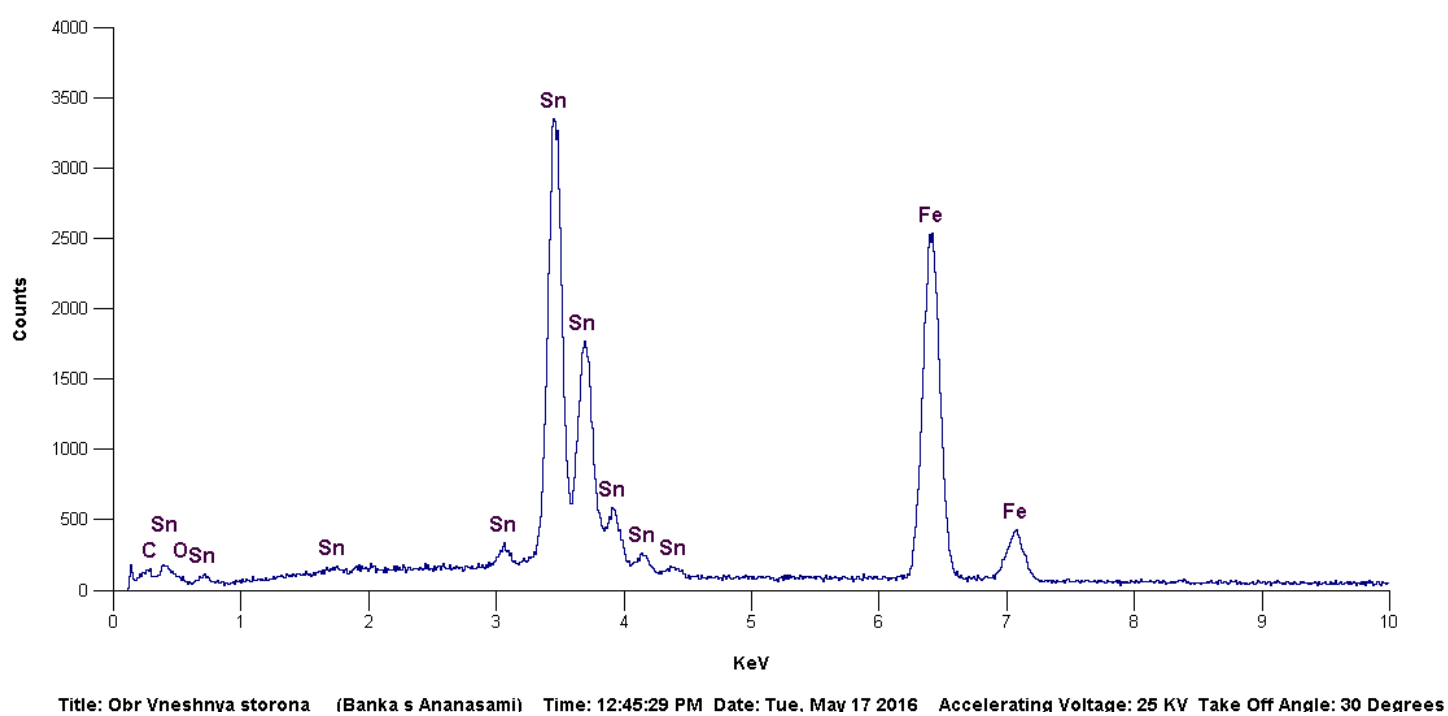

Рисунок 2. Спектр характеристического рентгеновского излучения внешней поверхности банки [8]

Figure 2. The spectrum of characteristic X-ray radiation of the outer surface of the can [8]

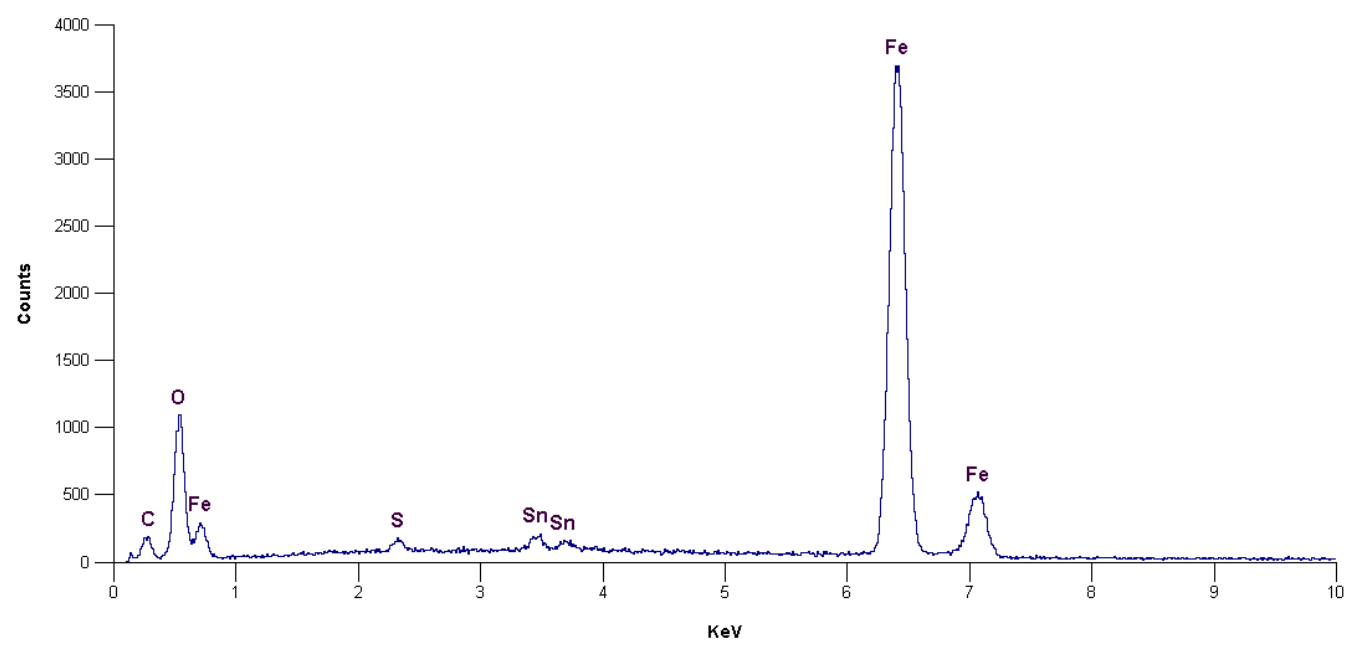

Рисунок 3. Спектр характеристического рентгеновского излучения внутренней поверхности банки, рыжий налет [8]

Figure 3. The spectrum of characteristic X-ray radiation of the inner surface of the can, red plaque [8]

Поскольку процесс коррозии металла виден отчетливо, можно говорить о том, что он начался еще до вскрытия банки, в процессе хранении, а при попадании кислорода внутрь банки, процесс быстро интенсифицировался.

При разработке новых упаковочных материалов должно происходить оценивание уровня риска для будущих потребителей от потенциально опасных химических соединений, которые могут содержаться как остаточные в упаковочном материале. Миграция низкомолекулярных химических веществ из упаковочных материалов выше некоторого установленного порогового значения представляет собой значительный риск: например, мышьяк в металлических сплавах, алюминий, хром и марганец - в стеклянной таре; остаточные мономеры в полимерах и др. Подобный риск возникает и при использовании в упаковке вторичных материалов - материалов рециклинга. 
Для разных типов упаковки рециклинг осуществляется по-разному: стекло и металлы переплавляют, макулатуру вводят в состав водной пульпы при производстве бумаги и картона. При этом осуществляется регламентация марок сплавов, марок стекла, картонной и бумажной упаковки. В литературе, в том числе научно-популярной, посвященной вопросам экологии, большую тревогу вызывает формирование так называемого «микропластика» микрочастиц полимеров, которые в виде мелких кусочков упаковки загрязняют окружающее пространство, и главным образом - поверхность мирового океана. К сожалению, возникает ложное впечатление, что только отходы полимеров загрязняют окружающую среду. Это очень заметная, видимая, часть общего загрязнения, потому что плотность полимеров,

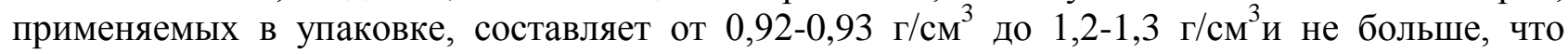
сравнимо с плотностью морской воды или намного меньше нее. Бутылочное стекло обкатывается до размеров гальки, а металл покоится на дне водоемов и корродирует. Реально обладает способностью к микробиологическому разложению традиционная упаковка из картона и бумаги, как представитель класса полисахаридов. В литературе много работ, которые посвящены расчету «индекса экологичности», «углеродного следа» при производстве упаковки в виде парниковых газов [9]. Но основной тенденцией в развитии научных направлений является поиск биоразлагаемых полимеров для упаковки, чтобы они могли ассимилировать в природной среде.

Синтез гетероцепных кислородсодержащих полимеров, например полимеров класса полиэфиров, полимеров с большим количеством полярных групп - $\mathrm{OH}-$; $\mathrm{CO}-$; $\mathrm{COO}-$ и аналогичных, приводит к тому, что полимер становится гидрофильным и способным иммобилизировать большое количество влаги. Именно это является важной предпосылкой для процесса биоразложения полимера. К настоящему времени разработано большое количество полимерных композиций на основе водорастворимых полимеров - ПВС, производных молочной кислоты, эфиров валериановой кислоты и т.п. Одно из направлений развития ассортимента упаковки - комбинирование водорастворимых полимеров с картоном, бумагой, что позволяет синтетическому полимеру разлагаться почти с такой же скоростью, как и природной целлюлозе

Автор полагает, что наполнение неполярных синтетических полимеров биоразлагаемыми органическими добавками может привести в тупик, поскольку увеличит в будущем объем «микропластика», но не решит проблему биоразложения неполярного полимера. Более разумным для уменьшения отходов полимеров считается «вторая жизнь» упаковки через технологию рециклинга: как технология bottle-to-bottle, так и использование отходов упаковки в других товарных продуктах (опалубка для строительства, добавки к асфальту, изделия технического назначения).

Согласно современной Глобальной стратегии по защите окружающей среды, разработанной $\mathrm{OOH}$, в том числе и от отходов из полимерных материалов, вторичная переработка пластмасс должна стать рентабельной для всех предприятий. Основные усилия производителей полимерной упаковки должны быть направлены на сокращение отходов полимеров и их выбросов в окружающую среду. По прогнозам аналитиков, к 2024 г. должен произойти рост рынка вторичной переработки полимеров почти в 2 раза. Среди полимеровлидеров называют полиэтилентерефталат (ПЭТФ, РЕТ) и полиэтилен (ПЭ, РЕ), которые в больших объемах используют для производства жесткой и мягкой (гибкой) упаковки.

Стадии жизненного цикла упаковки различны в зависимости от того, является она первичной потребительной или вторичной потребительской, а также и транспортной упаковкой. Ее долговечность должна быть различной в зависимости от срока хранения товара, от вида пищевого продукта с ограниченным сроком годности. Долговечность упаковочного материала должна находиться в гармонии со сроком годности продукции, но как известно, она намного превышает его, поэтому возникает дополнительная проблема утилизации упаковки.

ПЭТФ относится к классу полиэфиров, гетероцепной полимер с высокой температурой плавления. Он имеет наиболее удачное сочетание прозрачности, прочности и 
селективной проницаемости, поэтому хорошо удерживает углекислый газ и применяется для производства бутылок для пищевых жидкостей. Возможность его многократной переработки не требует переводить этот полимер в статус «биоразлагаемый», поскольку его перерабатывают в волокна, трикотаж, ткани, пленку, геотекстиль и пр. Практически, он является ценным сырьем, так же, как и ПЭ, который перерабатывают в мешки для мусора, разовую транспортную тару, садовые компостеры, упаковку для агрохимикатов и т.п.

Стратегия защиты окружающей среды привела многие компании к использованию вторичного ПЭТФ в таре, контактирующей с пищевыми продуктами. Например, компания Данон анонсировала, что в 2021 г. планируется производство и использование бутылок, которые состоят на 100\% из вторично переработанного материала [10]. Однако, это не означает что происходит $100 \%$ переработка всех отходов упаковки, и связано это с многими техническими проблемами, в том числе и безопасностью материалов.

В России в настоящее время вторично перерабатывают ПЭ $(20 \%)$, ПП (17\%) и ПЭТФ (12\%) [11]. Для рециклинга полимеров применяют различные методы, которые зависят от химического строения мономерного звена полимера. Например, может применяться как химический рециклинг: деполимеризация и новый синтез (например, полистирол), так и механический рециклинг: измельчение - деконтаминация - гранулирование - добавление к первичному полимеру (ПЭТФ, ПЭ).

Проблемы, которые возникают при работе с вторичными полимерами можно разделить на три основных блока: идеология использования вторично переработанных полимеров в упаковке; теоретические основы применения полимеров рециклинга; безопасность смесевых композиций с вторичным полимером.

При использовании отходов упаковки (полимеры рециклинга) нужно дать ответ на такие вопросы как: долговечность упаковки (время жизни и стабильность); какие синтетические полимеры должны быть биоразлагаемыми, а какие могут участвовать в технологиях механического рециклинга.

Теоретические основы включают вопросы: какие пищевые продукты могут находиться в длительном контакте с полимерной упаковкой, содержащей различные химические низкомолекулярные добавки; как обеспечить безопасность полимерной упаковки с рециклированным (вторичным) полимером; какие методы являются наиболее пригодными для достоверной идентификации включения вторичного полимера в состав упаковки (защита от фальсификации материалов).

Вопросы безопасности связаны с:

- установлением происхождения отхода;

- контролем состава полимеров механического или химического рециклинга;

- возможностью вторичного использования полимера для контакта с непродовольственными или продовольственными товарами;

- установлением возможности применения упаковки с вложением рециклированного полимера для контакта с пищевыми продуктами.

В работе [12] описан подход контролируемого старения полимерного материала для моделирования процессов, происходящих с полимерной упаковкой после ее использования, поскольку предыстория полимерного материала не всегда является установленной на предприятии по переработке.

После неоднократной переработки полимера в экструдере при температурах 245-270 ${ }^{\circ} \mathrm{C}$ от цикла к циклу происходило «накопление» в полимере изменения структуры в результате термомеханического старения. Следствием является увеличение показателя текучести расплава исходного ПЭТФ (1 цикл) и конечного состояния (4 цикл) почти в 1,5 раза.

В процессе старения полимер изменяет внешний вид от прозрачного блестящего до полупрозрачного, пожелтевшего в третьем цикле и непрозрачного, пожелтевшего в 4 цикле термомеханического старения. Изменение микроструктуры полимера от цикла к циклу подтверждается на микрофотографиях, полученных с помощью сканирующей электронной 
микроскопии. Плавно снижается величина относительного удлинения при разрыве, и проходит через небольшой максимум величина разрушающего напряжения. Происходит окисление полимера, что подтверждается увеличением числа кислородсодержащих групп по результатам анализа ИК-спектров. Предполагается, что изменение химической структуры в полимере, содержащем материалы рециклинга, можно идентифицировать при экспертизе методом ИК-Фурье спектроскопии [12-13].

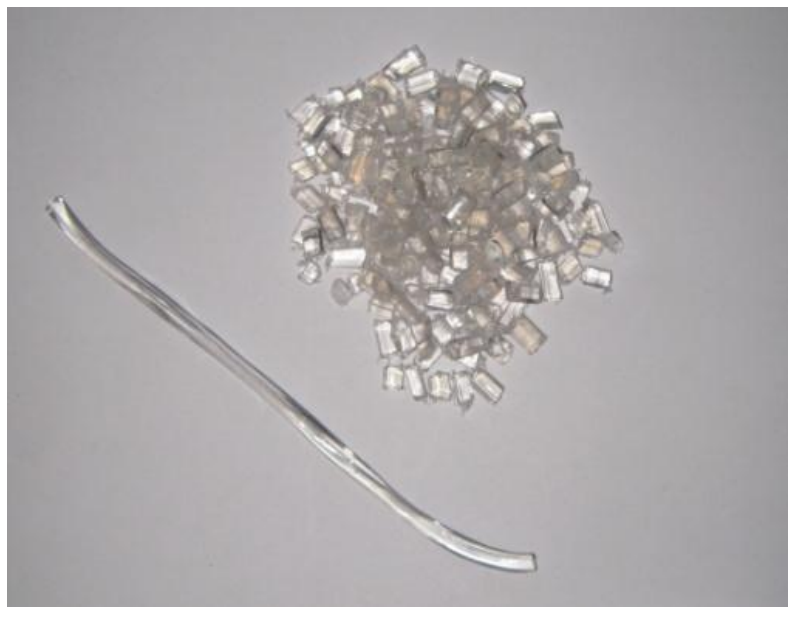

a

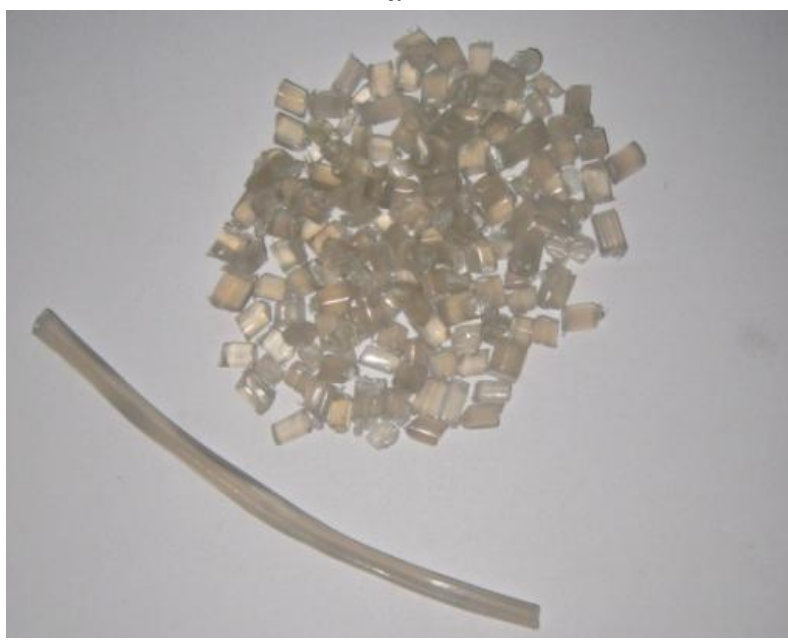

B

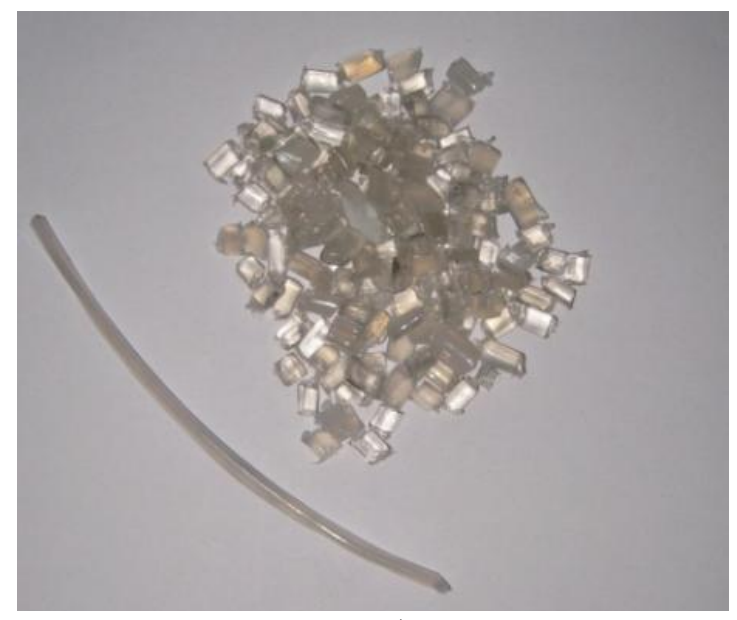

б

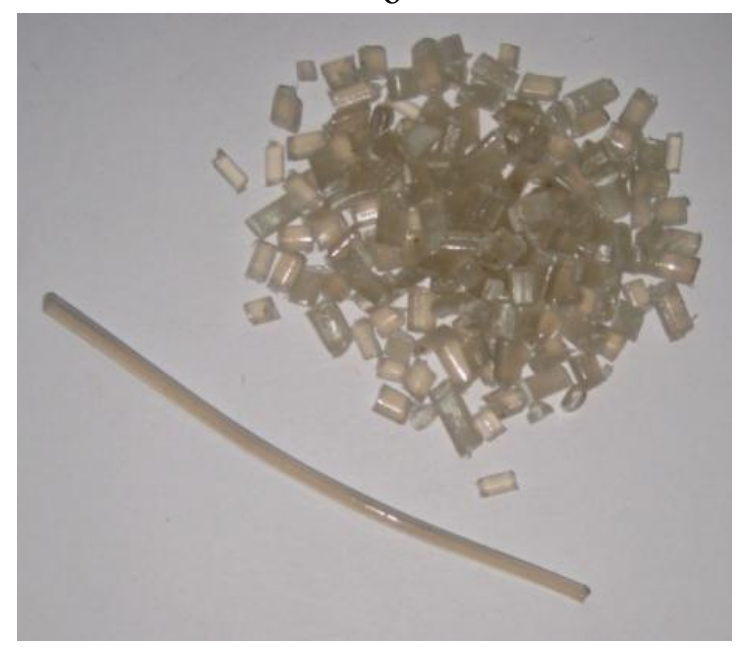

$\Gamma$

Рисунок 4. Внешний вид стренг и гранул ПЭТФ в процессе контролированного термомеханического старения: а - исходный; после второго (б), третьего (в) и четвертого (г) циклов [12]

Figure 4. Appearance of strands and PET granules in the process of controlled thermomechanical aging: a - initial; after the second (b), third (c) and fourth (d) cycles [12]

Оптические микрофотографии, приведенные на рис. 4, а также данные ИКспектроскопии и электронной микроскопии (SEM) отчетливо показывают заметное влияние процесса старения на исходный первичный полимер, циклы 2-4 - это модель полимера, возвращенного в производство на предприятии. Менее понятна история полимеров, взятых на полигонах твердых бытовых отходов - ТБО.

Поэтому для ПЭТФ первичного, вторичного, полученного из отходов производства (марка А), и флексов, приобретенных на складе твердых бытовых отходов, проведены дополнительно исследования безопасности методом биотестирования.

Так как выбранные материалы применяются для упаковки бутилированной воды, было принято решение руководствоваться методическими рекомендациями по применению методов биотестирования для оценки качества воды в системах хозяйственно-питьевого 
водоснабжения, а именно ПНД ФТ 14.1:2:3:4.12-06 [14]. Измерение проводилось в течение 168 часов. Опыт прекращается, если в течение 24 часов во всех вариантах наблюдается гибель более $50 \%$ рачков.

При определении острой токсичности устанавливают:

среднюю летальную кратность разбавления вод, водных вытяжек, вызывающую гибель 50 \% тест-объектов за 72-часовую экспозицию (ЛКР50-72);

безвредную кратность разбавления вод, водных вытяжек, вызывающую гибель не более 10 \% тест-объектов за 72-часовую экспозицию (БКР10-72).

Для определения острой токсичности исследуемых вод, водных вытяжек осадков сточных вод и отходов рассчитывается процент погибших в тестируемой воде дафний (A, \%) по сравнению с контролем:

$$
A=\frac{\bar{X}_{\mathrm{K}}-\bar{X}_{\mathrm{T}}}{\bar{X}_{\mathrm{K}}} \cdot 100 \%,
$$

где $\bar{X}_{\mathrm{K}}$ - количество выживших дафний в контроле (среднее значение из пяти параллельных определений); $\bar{X}_{\mathrm{T}}$ - количество выживших дафний в тестируемой воде (среднее значение из пяти параллельных определений).

Для расчета корректного числа «насыщенности» добавляемого к воде полимера исходили из того, что масса 500 мл бутылки воды, произведенной из ПЭТФ, составляет 28 г. Так как ПЭТФ первичный и ПЭТФ вторичный прошли должную деконтаминацию, а ПЭТФ флексы нет, ввиду неизвестного происхождения и приобретения непосредственно со склада ТБО, то ПЭТФ флексы дополнительно очистили в мыльном растворе, и биотестирование проводилось с двумя видами образцов: отмытыми и не отмытыми.

В качестве тест-объектов для проверки ПЭТФ использовали дафний Daphnis magha Straus. Биотестирование проводилось в пробирках объемом 100 мл. Расчет величины А по формуле (1) показал, что:

для исходного, первичного ПЭТФ А=7\%,

для ПЭТФ вторичного А $=26 \%$

флексы отмытые: $\mathrm{A}=44 \%$

флексы не отмытые: $\mathrm{A}=62 \%$

Таким образом, показано, что дафнии, которые размножаются в контрольной среде, не размножаются в контакте с полимерами, а также выявлена остаточная токсичность как вторичного ПЭТФ, который имеет гигиенический сертификат, таки ПЭТФ флексов.

В качестве оксо-разлагаемой упаковки было выбрано два образца промышленной полимерной упаковки, которые содержали разные оксо-разлагаемые добавки: $\mathrm{d} 2 \mathrm{w}$ и «REVERTE». В качестве тест-объектов использовали инфузорий Tetrahymena pyriformis. Исследования показали, что заявленная добавка может быть только декларацией. Проведенный анализ микроструктуры и химического состава пленок методом рентгеноструктурного микроанализа выявил отсутствие ионов переходных металлов. Обнаружено присутствие углерода (пик интенсивностью 7000 отн. ед.), кислорода (интенсивность пика менее 200 отн. ед.), и незначительное количество ионов кальция (интенсивность пика около 500 отн. ед.). Тест-объекты инфузории вели себя практически одинаково в контрольных растворах и в присутствии исследуемых пленок с оксо-добавкой $\mathrm{d} 2 \mathrm{w}$. Это может более достоверно свидетельствовать об отсутствии этих добавок в пленках. Точность определения добавки ионов металлов выше, нежели погрешность методики, поскольку чувствительность метода исследования не ниже 0,1 атом. \% [15].

Практическая значимость методов биотестирования для упаковочных материалов в том, что они могут позволить без применения модельных сред и санитарно-химических исследований давать сравнительно быстрое заключение о безопасности материала и его пригодности для контакта с пищевыми продуктами только по результатам взаимодействия продуктов миграции с живыми тестовыми микроорганизмами [16]. Такой подход позволяет проводить экспресс-оценку пригодности при разработке новых материалов для упаковки. 
Полученные результаты. Анализ проблем безопасного использования упаковки для контакта с пищевыми продуктами показал, что при разработке новых упаковочных материалов должно происходить оценивание уровня риска для будущих потребителей от потенциально опасных химических соединений, которые могут содержаться как остаточные в упаковочном материале. Миграция низкомолекулярных химических веществ из упаковочных материалов выше некоторого установленного порогового значения представляет собой значительный риск: например, алюминий, хром и марганец - в стеклянной таре; остаточные мономеры в полимерах и другое. Подобный риск возникает и при использовании в упаковке вторичных материалов - материалов рециклинга.

В условиях старения полимерного упаковочного материала показано заметное окисление и исходного первичного полиэтилентерефталата, и возвращенного в производство, коррозия полимера и слоя олова под действием пищевых кислот. Методом биотестирования выявлена остаточная токсичность как вторичного ПЭТФ, который имел сертификат, так и ПЭТФ флексов.

Показана перспективность использования методов биотестирования упаковочных материалов как позволяющих без применения модельных сред и санитарно-химических исследований давать сравнительно быстрое заключение о безопасности материала и его пригодности для контакта с пищевыми продуктами.

Выводы и дискуссионные вопросы. В заключении автору хотелось бы поставить несколько вопросов, которые необходимо решать разработчикам новых упаковочных материалов и упаковки.

1. Каким полимерам: синтетическим или искусственным, необходимо придавать статус «биоразлагаемый»? Правильно ли использование оксо- и биоразлагаемых добавок в материалах, которые применяют для изготовления первичной упаковки (тары) для пищевых продуктов? Для каких конкретных однородных групп продуктов, а также для сухих, влажных или жидких - их применять?

2. Какие именно полимеры можно ламинировать в многослойные системы с полимерами, которые разлагаются сами - например, с целлюлозой и ее производными?

3. Если введение макулатуры допускают в картон группы хром-эрзац в качестве среднего слоя, то и вторичный полимер нужно вводить только в средний слой материала, чтобы первичный, чистый полимер, контактировал непосредственно с пищевым продуктом.

4. Очень важный вопрос - нужно ли «портить» первичный полимер добавками вторичных материалов? Возможно - более правильно ввести градацию сорта упаковки, чтобы обеспечить требуемый уровень качества: сорт А - первичный материал; сорт Б - 100\% вторичный материал.

От правильных ответов на эти вопросы зависит безопасность экологии человека, поскольку эффект накопления малых примесей в организме может привести к переходу количества в новое качество, или кумулятивному эффекту, что скажется в дальнейшем на его здоровье. Переход на декларирование упаковки, которая падает на предприятияпроизводители, по ТР ТС 005/2011, потребует постоянного мониторинга качества и безопасности упаковки на всех стадиях обращения: от производства - торговли потребления - утилизации.

\section{Библиографический список}

1. Стратегия развития машиностроения для пищевой и перерабатывающей промышленности Российской Федерации на период до 2030 года: распоряжение Правительства РФ от 30.08.2019 г., № 1931-р [Электронный ресурс]. Доступ из справ.правовой системы «КонсультантПлюс».

2. Чалых, Т. И. Товароведение упаковочных материалов и тары для потребительских товаров [Текст] / Т. И. Чалых, Л. М. Коснырева, Л. А. Пашкевич. - М.: Академия, 2004. - 368 c. 
3. Продовольственные потери и пищевые отходы в контексте устойчивых продовольственных систем: доклад Группы экспертов высокого уровня по вопросам продовольственной безопасности и питания Комитета по всемирной продовольственной безопасности [Электронный ресурс]. - ГЭВУ, Рим. 2014 г. - Режим доступа: http://www.fao.org/3/a-i3901r.pdf

4. Бойко, А. Г. Перспективы развития упаковки в пищевой индустрии [Текст] / А.Г. Бойко // Современное состояние и перспективы развития упаковки в пищевой промышленности: сб. материалов конф. - М.: МГУПП, 2018. - С. 10-11.

5. Крутовский, А. В. Требования к безопасности упаковки в международном законодательстве [Текст] / А. В. Крутовский, Т.И. Чалых // Современное состояние и перспективы развития упаковки в пищевой промышленности: сб. материалов конф. - М.: МГУПП, 2018. - С. 11-13.

6. Синицына, М. В. Влияние упаковки на основе модифицированного вторичного полиэтилентерефталата на качество пищевых продуктов : НКР [Текст]. - М.: РЭУ им. Г.В. Плеханова, 2020.

7. Технический регламент Таможенного союза ТР ТС 005/2011 «О безопасности упаковки» (с изм.), 2020.

8. Чалых, Т. И. Экспертиза качества упаковки, используемой для консервированных фруктов [Текст] / Т. И. Чалых, К. Галынская, А. Щербина // Качество и безопасност на потребителски стоки: сб. статей. - Варна: Наука и икономика; Икономически университет, 2017.

9. https://www.carbontrast.com

10. https://www.danone.com/impact/planet/packaging-positive-circular-economy.html

11. Кузин, И. А. Анализ рынка вторичного полимерного сырья [Текст] / И. А. Кузин, А. Н. Васильев, В. В. Меньшиков // Успехи в химии и химической технологии. - 2017. - Т. XXXI, № 15. - С. 54-55.

12. Кирш, И. А. Регулирование физико-механических свойств вторичного полиэтилентерефталата путем химической и физической модификации [Текст] / И. А. Кирш, Т. И. Чалых [и др.] // Вестник Казанского технологического университета. - 2015. - Т.18, вып.7. - С. 79-82.

13. Чалых, Т.И. Безопасность упаковки с рециклированным содержимым [Текст] / Т.И. Чалых, Я.Е. Ружникова, М.В. Синицина // Первый международный конгресс «Экологическая, продовольственная и медицинская безопасность человечества», ноябрь 2011 г.: материалы конгресса. - 2011. - Т.2. - С. 252-254.

14. ПНД Ф Т 14.1:2:3:4.12-06 «Токсикологические методы контроля. Методика измерений количества Daphnia magna Straus для определения токсичности питьевых, пресных природных и сточных вод, водных вытяжек из грунтов, почв, осадков сточных вод, отходов производства и потребления методом прямого счета», 2014. - С. 38.

15. Чалых, А.Е. Электронно-зондовый микроанализ в исследовании полимеров [Текст] / А.Е. Чалых, А.Д. Алиев, А.Е. Рубцов. - М.: Наука, 1990. - 192 с.

16. Елисеева, Л.Г. Перспективные методы биотестирования безопасности продовольственных товаров [Текст] / Л.Г. Елисеева, И.Б. Леонова, О.В. Юрина // Товаровед продовольственных товаров. - 2014. - № 12.

\section{References}

1. The strategy for the development of mechanical engineering for the food and processing industry of the Russian Federation for the period up to 2030: order of the Government of the Russian Federation of 08.30.2019, № 1931-r. http://www.consultant.ru/document/cons_doc_LAW_332931/

2. Chalykh, T.I., Kosnyreva, L.M. \& Pashkevich, L.A. (2004). Commodity research of packaging materials and containers for consumer goods. Moscow. Academy. 368 p. 
3. Food Losses and Waste in the Context of Sustainable Food Systems. Report of the High Level Panel of Experts on Food Security and Nutrition of the Committee on World Food Security. HLPE, Rome. 2014. URL: http://www.fao.org/3/a-i3901r.pdf

4. Boyko, A.G. (2018). Prospects for the development of packaging in the food industry. In: Sat. materials of the conference "Current state and prospects of development of packaging in the food industry". Moscow. MGUPP, 2018. Pp. 10-11.

5. Krutovsky, A.V. \& Chalykh T.I. (2018). Requirements for packaging safety in international legislation. In: Sat. materials of the conference "Current state and prospects of development of packaging in the food industry". Moscow. MGUPP, 2018. Pp. 11-13.

6. Sinitsyna, M.V. (2020). The influence of packaging based on modified recycled polyethylene terephthalate on the quality of food. Moscow: PRUE. G.W. Plekhanov.

7. Technical Regulations of the Customs Union TR CU 005/2011 "On the safety of packaging", (as amended).. URL: http://www.consultant.ru/document/cons_doc_LAW_332931/

8. Chalykh, T.I. (2017). Examination of the quality of packaging used for canned fruits. In: Quality and safety of consumer goods. Articles from a round table with international participation. Varna. Science and Economics, University of Economics.

9. https://www.carbontrast.com

10. https://www.danone.com/impact/planet/packaging-positive-circular-economy.html

11. Kuzin, I.A., Vasiliev, A.N. \& Menshikov, V.V. (2017). Analysis of the market for secondary polymer raw materials. Advances in chemistry and chemical technology. XXXI (15). Pp. 54-55.

12. Kirsh, I.A. \& Chalykh, T.I. (2015). Regulation of physical and mechanical properties of secondary polyethylene terephthalate by chemical and physical modification. Bulletin of Kazan Technological University. 18 (7). Pp. 79-82.

13. Chalykh, T.I., Ruzhnikova, J.E. \& Sinitsina, M.V. (2011). Safety of packaging with recycled content. In: Materials of the First International Congress "Environmental, Food and Medical Security of Humanity". Moscow. PRUE. GW. Plekhanov. Vol. 2. Pp. 252-254.

14. PND FT 14.1: 2: 3: 4.12-06 "Toxicological control methods. Methodology for measuring the amount of Daphnia magna Straus to determine the toxicity of drinking, fresh natural and waste water, water extracts from soils, soils, sewage sludge, production and consumption waste by the direct counting method ", 2014. P. 38.

15. Chalykh, A.E., Aliev, A.D. \& Rubtsov, A.E. (1990). Electron probe microanalysis in the study of polymers. Moscow. Nauka. 192 p.

16. Eliseeva, L.G., Leonova, I.B. \& Yurina, O.V. (2014). Perspective methods of biotesting of food safety. J. Commodity expert of food products. Vol. 12. 